\title{
GEO/SQL V VODNEM GOSPODARSTVU
}

\author{
Andrej Vidmar in Mitja Brilly
}

Izvleček

UDK 628.1:91:681.3

Razuoj vodnega gospodarstua use bolj izpostavlja problem zbiranja in ažuriranja množice deskriptivnih in grafičnih vodnogospodarskih kot tudi drugih informacij, potrebnih pri vodnogospodarskem planiranju ter problem pretoka le-teh med posameznimi subjekti planiranja $v$ prostoru. Rešitev tega problema leži $v$ geografskih informacijskih sistemih - GIS. Clanek opisuje uporabnost programskega razvojnega orodja Geo/SQL v vodnem
gospodarstvu.

\section{Abstract}

UDC $628.1: 91: 681.3$

\section{GEO/SGL IN WATER RESOURCE MANEGEMENT}

The development of water resource management concepts shows the problem of collecting, combining, and using alphanumerical and graphical spatial data. The solution of this problem lies in the use of geographic information systems - GIS. This paper describes the usefulness of GIS programming tool Geo/SQL in water resources management.

\section{VODNOGOSPODARSKI INFORMACIJSKI SISTEM}

\section{GIS}

GIS (Geographic Informatic Systems) programska orodja so programske aplikacije, ki prikazujejo realni svet na digitalen in fleksibilen način.

GIS (Geographic Information System) je informacijski sistem za upravljanje prostorskih podatkov. Torej je GIS skupek organizacijskih zakonitosti, znanja osebja, podatkov, programske opreme, mehanske opreme in pretoka informacij, potrebnega pri upravljanju tako grafičnih kot tudi atributivnih prostorskih podatkov.

GIS kot celoto sestavlja: orgware, liveware-brainware, dataware, software, hardware in netware.

Mag. Andrej Vidmar dipl. ing. gr., prof. dr. Mitja Brilly dipl. ing. gr., Univerza v Ljubljani, FAGG - Hidrotehnična smer 
GIS so računalniške aplikacije narejene za zajem, vnos, pripravo, kontrolo, iskanje, sortiranje, zaščito, analizo, shranjevanje, prenos, konverzijo in prikaz (vizualizacijo) prostorsko opredeljenih podatkov.

GIS-i so se razvili iz (Burrough,1986):

- kartografije;

- računalniške grafike;

- fotogrametrije;

- prostorske analize;

- interpolacijskih tehnik;

- daljinskega zaznavanja.

Obravnavanje prostorskih problemov s pomočjo koncepta geografskih informacijskih sistemov - GIS se loči na dve vsebinsko različni področji (Globevnik, Vidmar, 1992):

- prvo je vzpostavljanje prostorskih podatkovnih baz in

- drugo področje uporabe GIS-ov so aplikacije - modeliranje, prostorska analiza, statistika, bilance,...

\section{VGIS}

VGIS je bodoči republiški vodnogospodarski informacijski sistem, kot del PIS, s specifično vodnogospodarskimi informacijami za potrebe vodnega gospodarstva, kot tudi za ostale uporabnike.

VGIS naj bi bil integriran kompletni sistem hardvera, softvera in datavera za upravljanje strokovno-tehničnih in upravno-pravnih informacij, katere potrebuje vodno gospodarstvo pri svoji dejavnosti.

VGIS naj bi vseboval 4D podatkovni model (prostor in časovne serije), kateri bi omogočal izvajanje najrazličnejših vodnogospodarskih prostorskih aplikacij. Tako naj bi vseboval vse potrebne vodnogospodarske, kot tudi ostale podatke katere potrebuje vodno gospodarstvo pri strokovno-tehnični in upravno-pravni dejavnosti na različnih nivojih kot so državni organi vkjučno $z$ izpostavami, druge vodnogospodarske organizacije, fakulteta in inštituti ter ostali uporabniki.

Potrebno se je zavedati, da $90 \%$ cene GIS-a odpade na podatke, zato naj bi bil podatkovni model VGIS-a grajen na osnovi internacionalnih podatkovnih standardov, kar bi mu zagotavljalo kvaliteto in uspešen nadaljnji razvoj.

\section{SPECIFIČNO VODNOGOSPODARSKI PODATKI}

Stanje prostora:

- hidrologija (hidrografija, hidromorfologija, hidrogeologija), mehanika voda 
(hidravlika), hidrobiologija, hidrokemija, hidroekologija, limnilogija, hidrometeorologija;

- vodnogospodarska infrastruktura (objekti in naprave), vodooskrba (pitna voda, tehnološka voda, namakanje), izraba vodne moči, odpadne vode, vodni turizem, šport in rekreacija ter podobno.

\section{Procesi:}

- vodnogospodarsko planiranje (vodnogospodarski načrti,...), vodnogospodarske študije in raziskave, ekonomika voda (vodna povračila,...), vodno pravo (zakonodaja, vodne pravice,...), vodnogospodarska proizvodnja in podobno.

Ostalo:

- vodnogospodarski arhiv (republiški in izpostave) ter knjižnica.

\section{SPECIFIČNO VODNOGOSPODARSKE APLIKACIJE}

\section{Strokovno-tehnične:}

- ocenjevanje in napovedovanje nizkih in visokovodnih pretokov, napovedovanje in ocena ogroženosti vzsled poplav in vodnih ujm, spremljanje (kartiranje) kvalitete površinskih in podzemnih voda, najrazličnejša poročila, vodne bilance, grafične prezentacije in podobno.

Slika 1: Shematski prikaz nekaterih vodnogospodarskih podatkov.

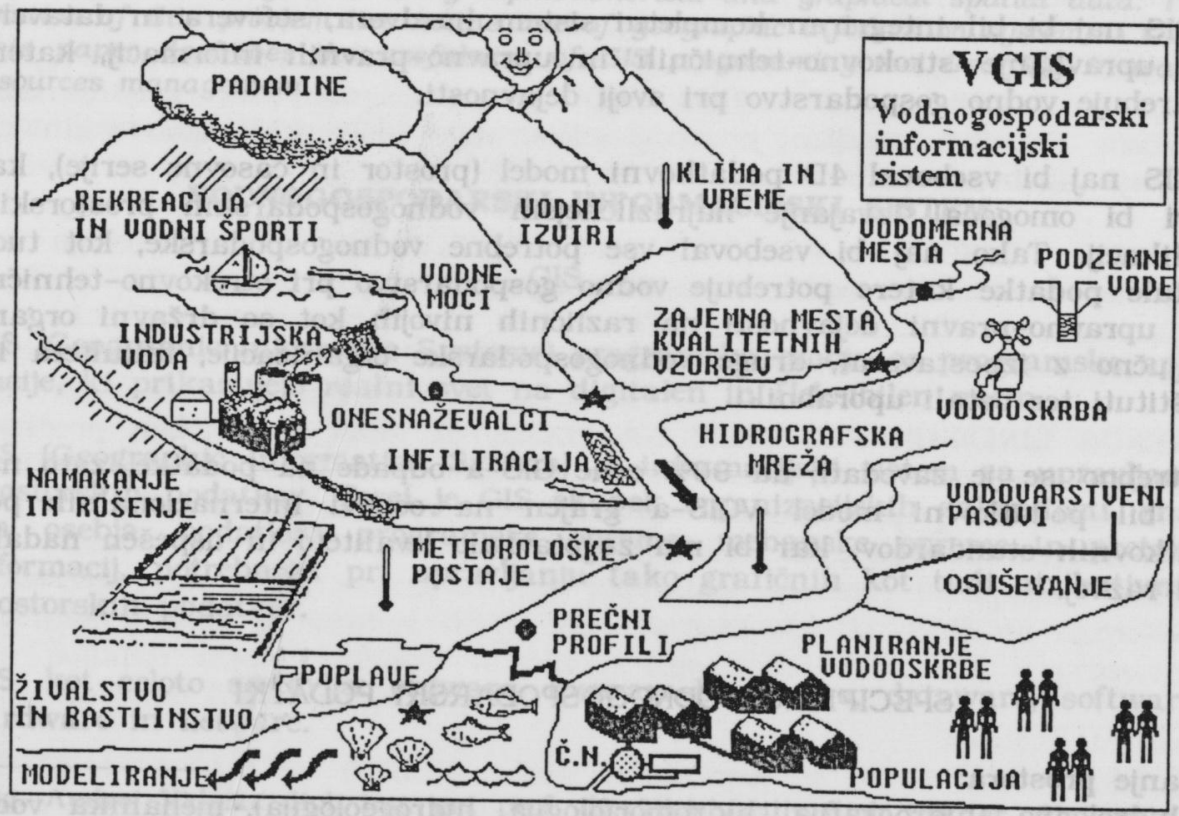


Upravno-pravne:

- vodenje upravnih postopkov, vodenje najrazličnejših drugih evidenc, izvajanje finančnih kalkulacij in podobno.

\section{GIS STANDARDI}

V svetovnem merilu se že oblikujejo nekateri institucionalni standardi za zapis, oblikovanje in prenos geokodiranih podatkov. Le ti naj bi omogočili izmenjavo geokodiranih podatkov med različnimi GIS-i. Poleg teh pa obstajajo tudi programski paketi oziroma GIS orodja, ki predstavljajo in postavljajo nekašne "de facto" standarde za formatne zapise prostorskih podatkov.

V ZDA je že izoblikovan predlog za sprejetje standardov za izmenjavo prostorskih podatkov (SDTS - Spatial Data Transfer Standard), ki so tik pred uradno potrditvijo za zvezne standarde. SDTS standardi bodo verjetno sprejeti tudi kot ANSI in ISO standardi, saj so temu primerno zasnovani, kajti SDTS so standardi standardov.

Slika 2: Risanje administrativnih mej (podatki Zavoda $R$ Slovenije za statistiko).




Nekaj institucionalnih formatov, priporočil in standardov za izmenjavo prostorskih podatkov(James L. McAbee III, 1992):

ATKIS Authoritative Topographic Cartographic Information System

* Working Committe of the Surveying Administrations of the States of the Federal Republic of Germany (AdV)

CCOGIF Canadian Council on Geomatics Interchange Format

* Canadian Council on Geomatics (CCOG)

CGIS Canadian Geomatics Interchange Standard

* Canadian General Standard Board (CGSB)- Committee on Geomatics

DIGEST Digital Information Geographic Exchange Standard

* NATO - Digital Geographic Information Working Group (DGIWG)

DLG, DLG-E Digital Line Graph, Digital Line Graph Enhanced

* United States Geological Survey (USGS)

DX-90 Speci. for the Exchange of Digital Hydrographic Data - 1990

* Committee on Exchange of Digital Data

ETF European Transfer Format

* Comite Europeen des Responsables de la Cartographie Officielle (CERCO)

GDF Geographic Data File

* PHILLIPS and BOSCH and the Cartographic Institute of Hanover University

MACDIF Map and Chart Data Interchange Format

* Canadian Hydrographic Service, Fisheries and Oceans

MDIF Mapping Data Interchange Format

* Ministry of Natural Resources, Government of Ontario

NTF National Transfer Format

* Working Party to Produce Nat. Stand. for the Transfer of Digital Map Data

SAIF Spatial Archive and Interchange Format

* Surveys and Resource Mapping Branch, British Columbia

SDTS - Spatial Data Transfer Standard

* Digital Cartographic Data Standards Task Force (DCDSTF)

TIGER - Topologically Integrated Geographic Encoding and Referencing System

* US Census Bureau 
Slika 3: Risanje lokacij-centroidov onesnaževalcev s pripadajočimi alfanumeričnimi atributi in glede na izbrane kriterije iz grafične in deskriptivne podatkoune baze Onesnaževalci 1986.

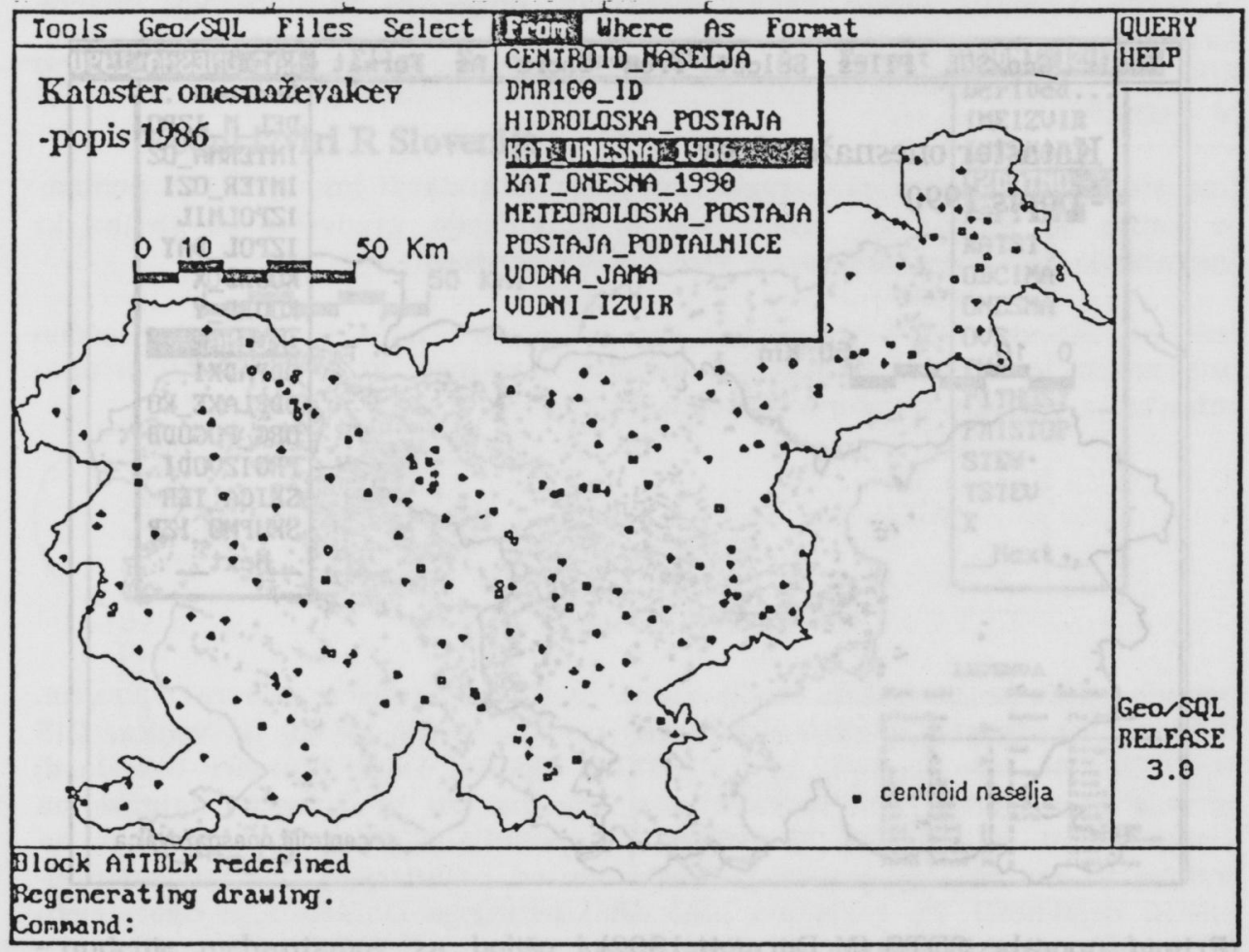

VPF Vector Production Format

* US Defense Mapping Agency (DMA)

SDTS standardi za prenos prostorskih podatkov vsebujejo:

- definicije terminoloških izrazov;

- specifikacije prenosa prostorskih podatkov;

- metode za opis kvalitete digitalnih kartografskih podatkov;

- izraze in definicije topografskih in hidrografskih bistvenih značilnosti (entitet).

SDTS standardi bodo:

- omogočali izmenjavo prostorskih podatkov med privatnim in družbenim sektorjem;

- povečali možnosti digitaliziranja, analiziranja in integriranja prostorskih podatkov za naraščajoče število aplikacij;

- izboljšali razpoložljivost informacij o kvaliteti podatkov, kot so izvor, popolnost, natančnost in logična konsistenca;

- omogočali ter pomagali uporabniku oceniti ustreznost podatkov za določen namen. 
Slika 4: Risanje lokacij-centroidov onesnaževalcev s pripadajočimi alfanumeričnimi atributi in glede na izbrane kriterije iz grafične in deskriptivne podatkoune baze Onesnaževalci 1990.

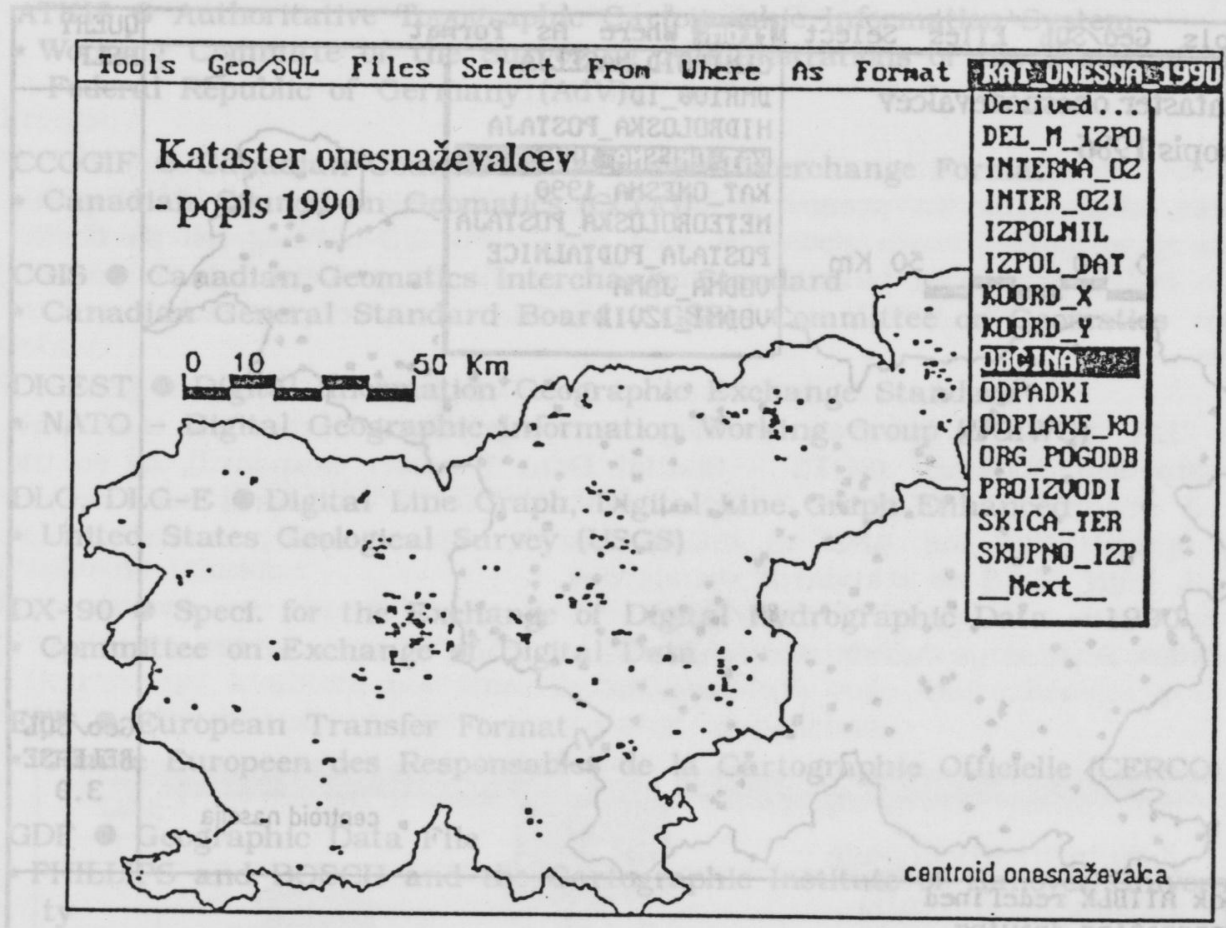

Primer uporabe SDTS (McDermott,1992):

NDSDBS -"The National Digital Spatial Data Base System" (Nacionalna podatkovna baza digitalnih prostorskih podatkov)

Ameriška zvezna vlada uporablja obstoječe digitalne kartografske podatkovne baze na osnovi tekočih potreb. Pomanjkanje enotnih standardov za prenose digitalnih prostorskih podatkov povečuje stroške in zavira prenose podatkov. $Z$ enotnimi standardi bo mogoča distribucija prostorskih podatkov med vsemi zveznimi inštitucijami.

NDSDBS je predlagana zvezna mreža neodvisno vzdrževanih digitalnih prostorskih baz. $\mathrm{V}$ mrežo podatkovnih baz na nacionalni ravni bodo vključene tradicionalne kartografske kategorije kot so hidrografija, meje, transport in nadmorske višine, skupno $\mathrm{z}$ ostalimi tematskimi kategorijami kot so zemlja, močvirja, geologija, vegetacija in demografija.

Nameni nacionalne podatkovne baze so: - podpiranje in pospeševanje uporabe SDTS; 
Slika 5: Risanje lokacij centroidov vodnih izvirov s pripadajočimi alfanumeričnimi atributi in glede na izbrane kriterije iz grafične in deskriptivne podatkoune baze Vodni izviri.

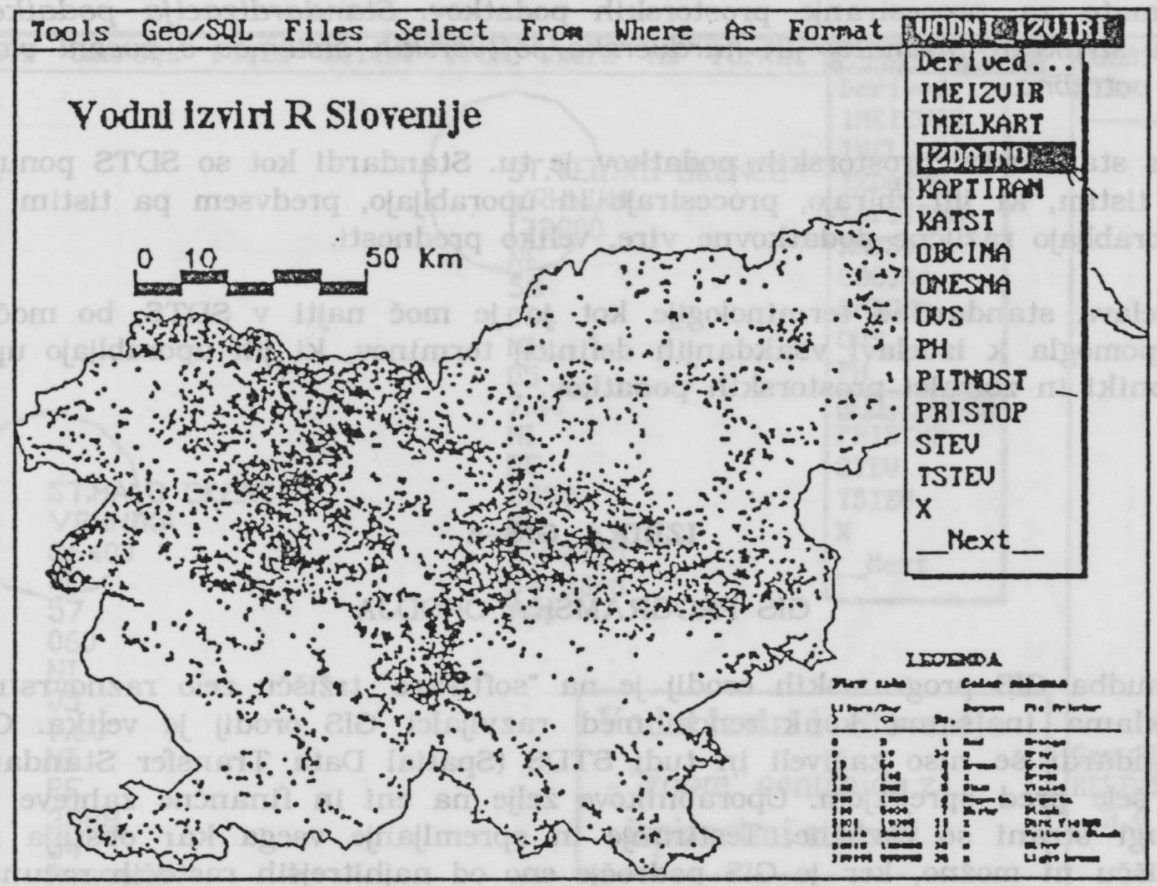

- nudenje mehanizmov za boljšo koordinacijo in standardizacijo vsebine in kvalitete podatkov (kot jih vsebujejo SDTS);

- nuditi bolj konsistentne in kompatibilne zvezne podatkovne baze;

- izboljšati učinkovitost in razpoložljivost podatkovnih baz, ki jih uporabljajo zvezne službe in drugi;

- informiranje uporabnikov, tudi potencialnih, o vrstah in vsebini podatkov, ki so na razpolago;

- pojasniti odgovornost zveznih služb za razvoj, vzdrževanje in distribucijo prostorskih podatkovnih baz.

Tak sistem podatkovnih baz zahteva, da bodo vse inštitucije, ki so odgovorne za informacije o prostoru, lahko ponudile podatke $\mathrm{v}$ formatu SDTS. Vsaka inštitucija bo odgovorna za neko podatkovno bazo, kar pomeni, da bo zbirala, shranjevala, obnavljala in vzdrževala podatke. Kategorije osnovnih podatkovnih baz kot so hipsografija, hidrografija, promet in meje, bodo določene pri USGS. Vse datoteke naj bi bile na razpolago vsem uporabnikom v formatu SDTS. Predvideno je tudi, da bi ostale inštitucije imele svoje podatke organizirane na podoben način, tako da bi uporabniki lahko te podatke dobili in jih prekrivali s podatkovnimi bazami USGS. Pri tem 
jim ne bi bilo potrebno poznati internega formata, ki ga uporabljajo odgovorne zbiralne inštitucije (Federal Interagency Coordinating Committee on Digital Cartography Standards Working Group, 1989). Pri iznosu podatkov $v$ SDTS formatu lahko vsaka inštitucija projektira in uporablja interne formate za procesiranje prostorskih podatkov. Standardizacija podatkovnih struktur, formatov in hardversko/softverskih sistemov $v$ zvezni vladi ni potrebna.

Čas standardov prostorskih podatkov je tu. Standardi kot so SDTS ponujajo tistim, ki jih zbirajo, procesirajo in uporabljajo, predvsem pa tistim, ki uporabljajo različne podatkovne vire, veliko prednosti.

Izdelava standardne terminologije kot jo je moč najti v SDTS, bo močno pripomogla $\mathbf{k}$ izdelavi vsakdanjih definicij terminov, ki jih uporabljajo uporabniki in zbiralci prostorskih podatkov.

\section{IZBIRA GIS-a}

\section{GIS PROGRAMSKA ORODJA}

Ponudba GIS programskih orodij je na "software" tržišču zelo raznovrstna. Reklama in sama konkurenca med razvijalci GIS orodij je velika. GIS standardi še niso zaživeli in tudi STDS (Spatial Data Transfer Standard) je šele pred sprejetjem. Uporabnikove želje na eni in finančne zahteve na drugi strani so različne. Testiranje in spremljanje vsega kar obstaja na tržišču ni možno, ker je GIS področje eno od najhitrejših rastočih računalniških dejavnosti. Po raziskavi ameriške inštitucije Daratech je bilo v letu 1990 GIS tržišče "težko" 530 milijonov USD s predvideno stopnjo nadaljne rasti od $32 \%$ do $35 \%$ v naslednjih štirih letih. Do sedaj je v svetu poznano preko 150 najrazličnejših programskih orodij na temo GIS, ki so povečini razviti $v$ ZDA in Kanadi. Torej takoj vidimo, da bomo na tržišču GIS programskih orodij le s težavo izbrali pravo GIS programsko orodje, ki bi ustrezalo vsem našim zahtevam.

Na FAGG Hidrotehničnem oddelku smo se s problemom izbire primernega programskega orodja srečali že nekako pred tremi leti. Do sedaj smo se seznanili $z$ najrazličnejšimi GIS paketi, ki smo jih spoznali doma kot tudi v tujini. Samo v enotedenski strokovni ekskuziji v Ultrechtu, Delftu, Wageningenu in Enshedeju na Nizozemskem smo videli več deset programskih orodij, kot so: Intergraf MGE in Tigris, ARC/INFO (VAX), GRASS, ATLAS, DELTAMAP/GENAMAP, GEOMAP, IMMS, ERDAS, ILWIS, IDRISI in nekaj drugih. Le-ti so se izvajali tako na PC-jih, Mac-ih in UNIX delovnih postajah kot so SUN, INTERGRAF in $\mathrm{HP}$, kot tudi na velikih računalniških sistemih tipa VAX in IBM. Pri tem smo spoznali, da se $z$ vprašanjem: "Kaj izbrati ?", ne srečujemo samo mi ampak tudi ostali, ki se $z$ GIS-i ukvarjajo že vrsto let. 
Slika 6: Risanje lokacij centroidov vodnih izvirov s pripadajočimi alfanumeričnimi atributi in glede na izbrane kriterije iz grafične in deskriptivne podatkoune baze Vodni izviri - zoomirano.

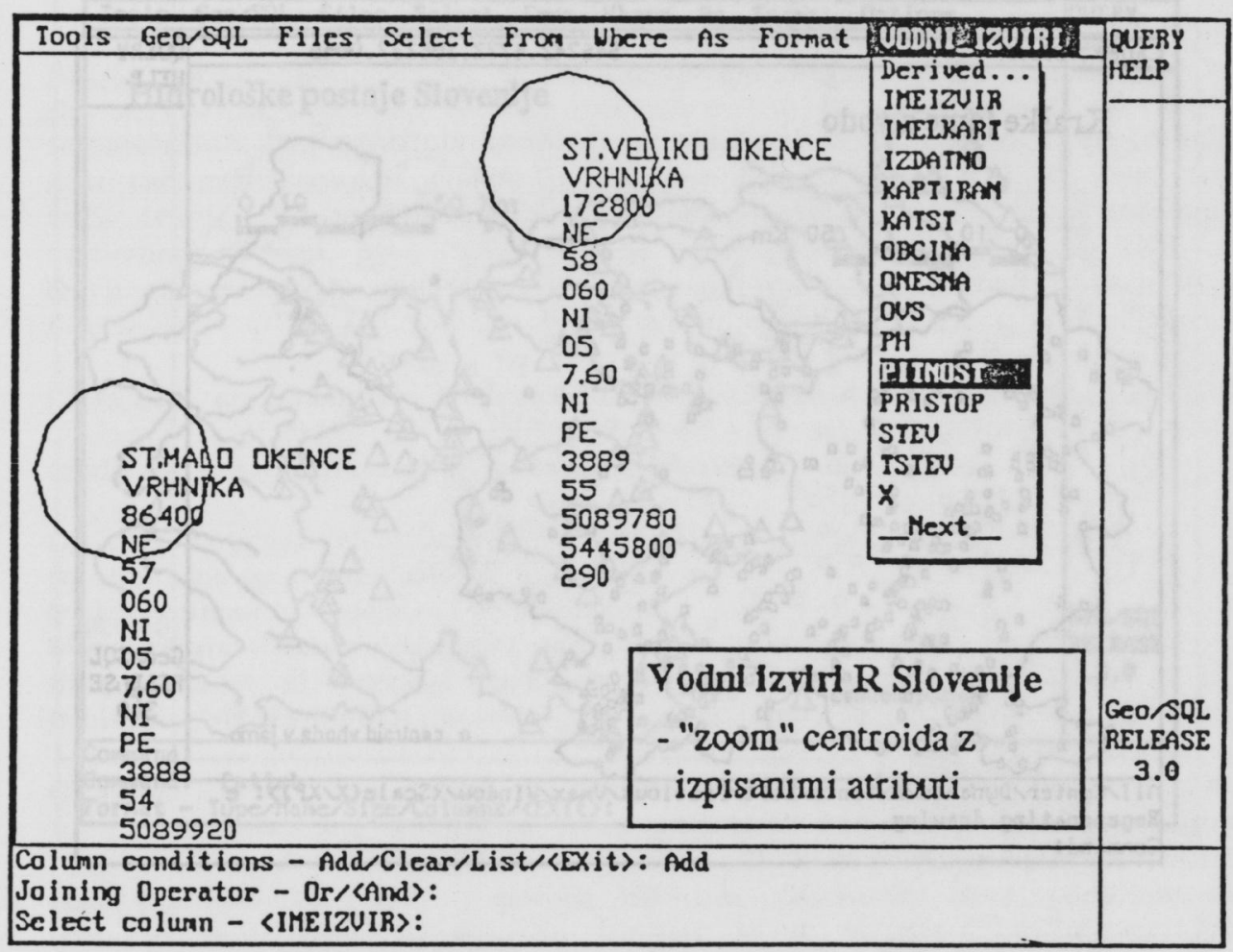

Ugotovili smo, da splošno in univerzalno GIS programsko orodje, katero bi zadostilo vsem našim zahtevam na PC računalnikih ne obstaja. Vsako GIS programsko orodje ima pred drugimi svoje specifične prednosti kot tudi slabosti.

$\mathrm{Na}$ Hidrotehničnem oddelku problem izbire primernega GIS programskega orodja rešujemo s tem, da pri svojem delu izberemo tisto orodje, ki je določeni aplikaciji najprimernejše.

\section{PREGLED IN PRIMERJAVA GIS ORODIJ}

Na FAGG Hidrotehničnem oddelku imamo:

- GIS programska orodja: PC ARC/INFO, IDRISI, SPANS (OS/2) in Geo/SQL

- GIS pripomočki:Geo/COGO, QuickSurf, ROOTS in DCA DTM 
Slika 7: Risanje lokacij centroidov vhodov v kraške jame (podatki Inštitut za raziskovanje krasa ZRC SAZU Postojna).

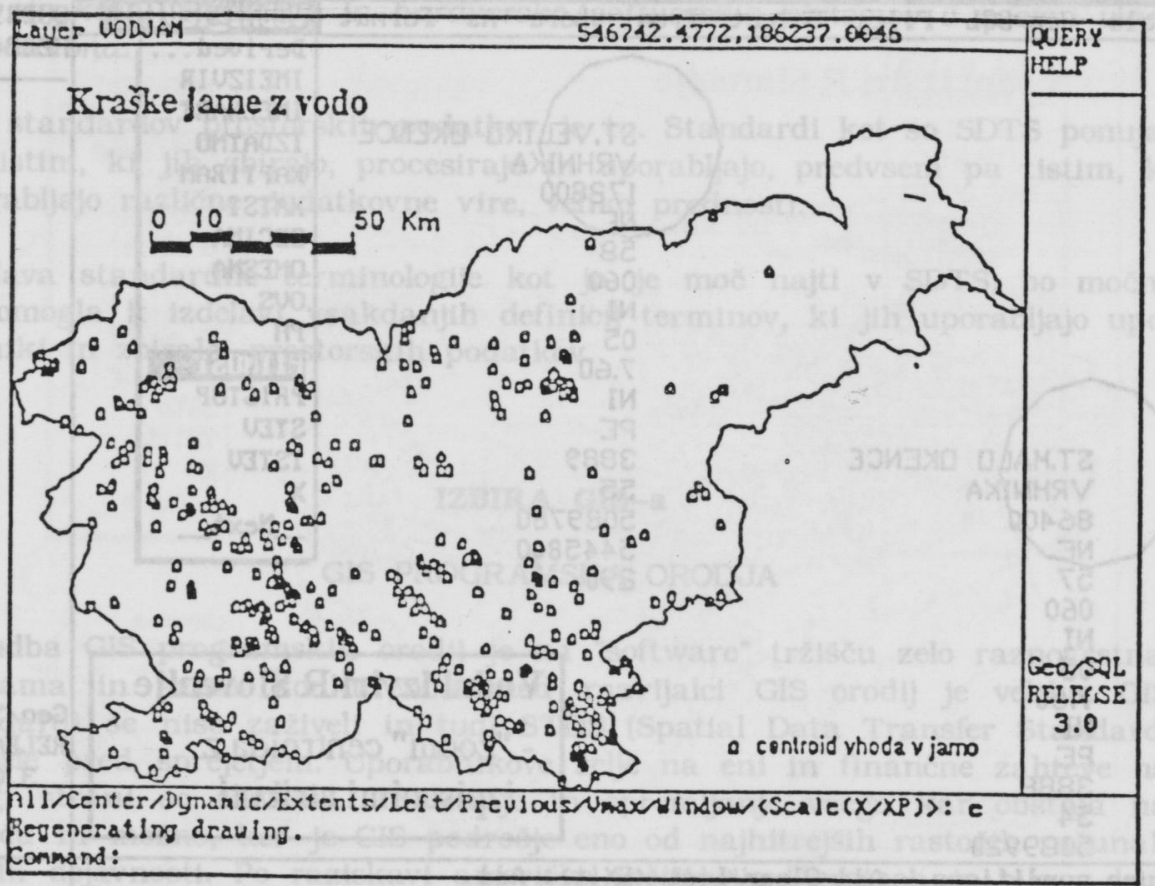

CAD orodja: AutoCAD1 1, AutoCAD12 in PC MicroStation 4.0

- RDBMS orodja: dBASE, Paradox, PC INFO in PC ORACLE

Sama primerjava in ocena uporabnosti GIS orodij, ki jih imamo v lasti, med seboj, je zaradi različnosti posameznih orodij zelo težavna. Vsako izmed zgoraj naštetih orodij ima nekaj dobrih in slabih lastnosti. Primerjava med njimi je odvisna tudi od tega kaj $z$ njimi počnemo oziroma kaj potrebujemo. Različne verzije teh orodij se zaradi hitre dinamike razvoja in tudi konkurence vrstijo zelo hitro, tako da je vsaka nadaljnja verzija popolnejša.

AutoCAD je program za računalniško podprto dizajniranje (CAD - Computer Aided Design). AutoCAD je najbolj univerzalen (modularnost, odprtost, programska razširljivost, možnost uporabe C- ja in AutoLISP-a, prilagodljivost za vsako uporabo,...) in najbolj razširjen ter uporabljan PC CAD paket. Do sedaj je v svetu registrirano okoli 800.000 uporabnikov, od tega 
Slika 8: Risanje lokacij centroidov hidroloških postaj (podatki HMZ).

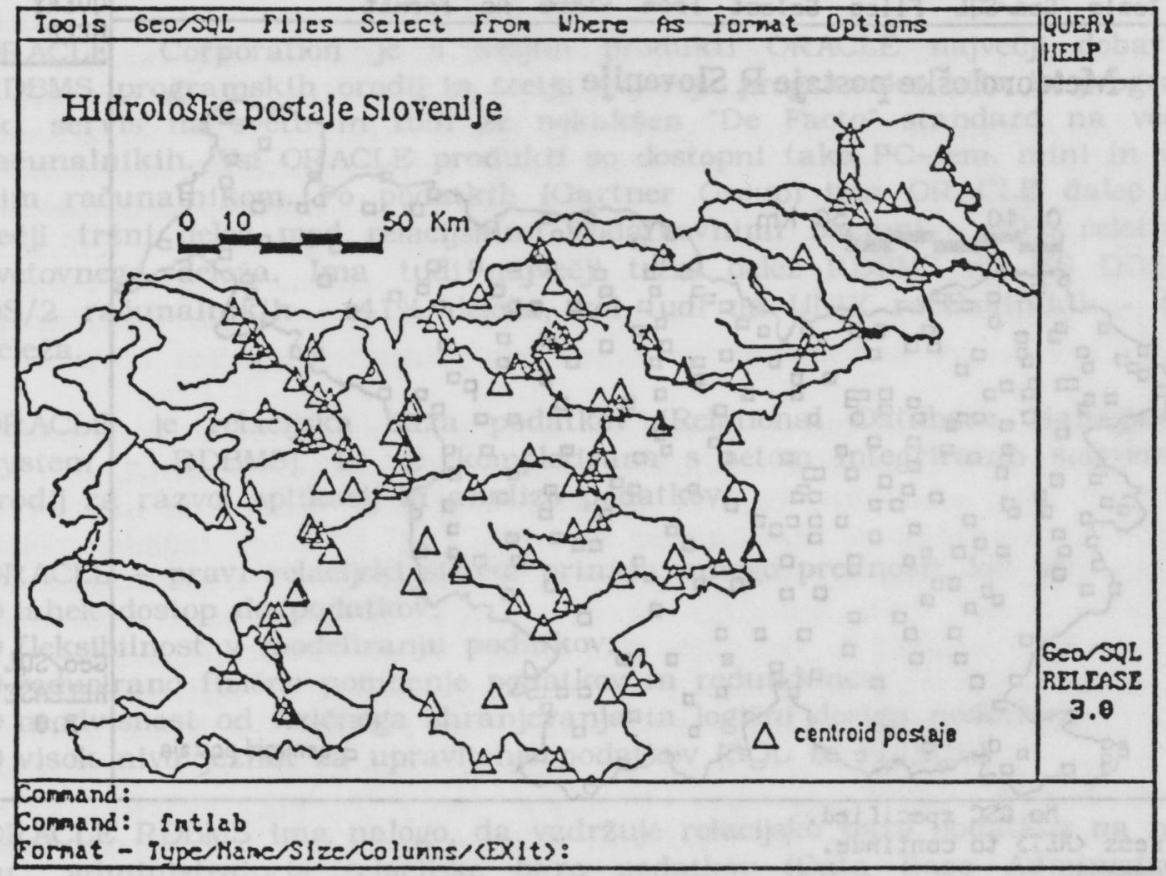

1/3 v Evropi. Tudi pri nas je že veliko instalacij, okoli 500 registriranih uporabnikov. Tako je AutoCAD bil in ostaja "De Facto" standard PC CAD-a in tudi na delovnih postajah se prebija $v$ ospredje, kar tudi nedvomno dokazuje množica hardverskih dodatkov, ki so se razvili izključno za in iz potreb AutoCAD-a. Njegova uspešnost na tržišču pa se je $z$ novo verzijo AutoCAD 12 še bolj utrdila.

AutoCAD verzija 12 prinaša okoli 174 izboljšav in novosti. Za uporabnika GIS so pomembne predvsem naslednje:

- nova tehnologija $\mathrm{z}$ vgrajenim 32 bitnim DLD "Display List" eliminira regeneracijo risbe pri premikanju in zumiranju (brez regeneracije 1:2000), kar je pri delu s prostorskimi grafičnimi podatki, zaradi količine, nadvse pomembno;

hitrejše risanje, na voljo je tudi WYSIWYG "Plot Preview"-pregled celotne slike pri izrisavanju na izhodno napravo;

- vsebuje AutoCAD SQL razširitev ASE (AutoCAD SQL Extentsion), kar 
Slika 9: Risanje lokacij centroidov meteoroloških postaj (podatki HMZ).

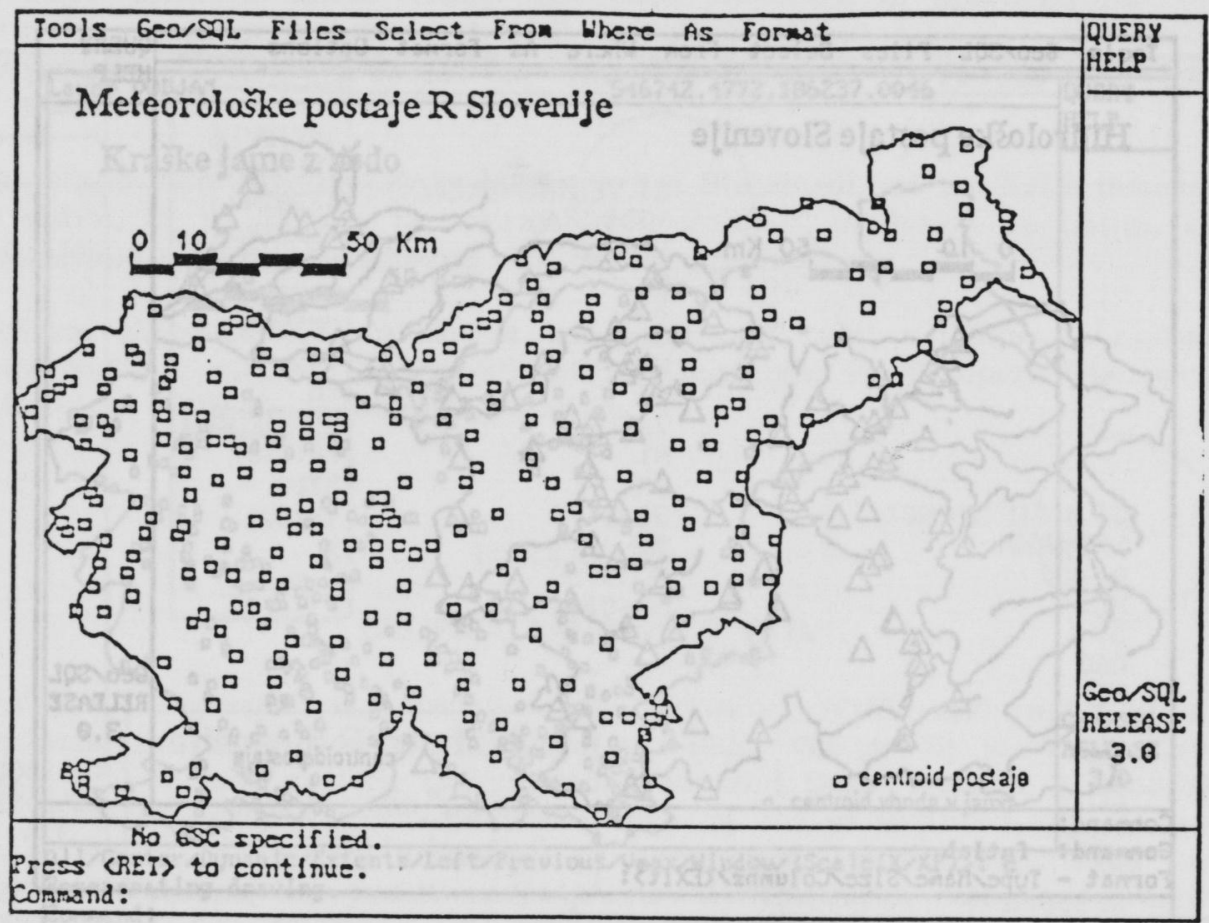

omogoča dostop do podatkov $\mathrm{v}$ standardnih relacijskih bazah preko SQL vmesnika, kot so dBASE, ORACLE in Paradox;

izvrstno 3D senčenje je odslej že vgrajeno, tako da ni potrebno dokupiti dragih tovrstnih programov. Tudi hitrost skrivanja nevidnih robov je $\mathrm{v}$ novi verziji do 100 krat hitrejše kot v verziji AutoCAD 11;

- v samo risbo AutoCAD-a sedaj lahko vstavljamo tudi rastrske slike v standardnih formatih TIFF, GIF in PCX;

verzija omogoča uporabo PostScript tipografij v AutoCAD risbi. Zunanja PostScript slika se lahko tudi vnese v AutoCAD in izriše;

- novo je večtočkovno kalibriranje grafične table, kar omogoča kompenzacijo kartnih podlog in spremembo projekcij. To je za GIS uporabnika tudi zelo pomembno.

V Sloveniji se je AutoCAD že zelo uveljavil. Za distribucijo tega programskega paketa skrbi en uradno registriran distributer in pet "Dealerjev". Prav tako obstaja pet registriranih šolskih centrov za šolanje kadrov za delo $s$ tem paketom, kar je nadvse pomembno. 
Še podatek, ki nakazuje AutoCAD-vo prodornost in uspešnost. AutoCAD je postal CAD standard trusta Daimler-Benz $z$ več kot 500 registriranimi kopijami. To je približno toliko uradnih registracij, kot jih je v vsej Sloveniji; seveda tu niso štete "črne" kopije.

ORACLE Corporation je s svojim produkti ORACLE največji dobavitelj RDBMS programskih orodij in tretja največja programska hiša in programski servis na svetu in tudi že nekakšen "De Facto" standard na večjih računalnikih. Vsi ORACLE produkti so dostopni tako PC-jem, mini in velikim računalnikom. Po podatkih (Gartner Group) ima ORACLE daleč največji tržni delež med relacijskimi podatkovnimi bazami - 30\% celotnega svetovnega deleža. Ima tudi največji tržni delež RDBMS na MS DOS in OS/2 računalnikih - $41 \%$ deleža, kot tudi na UNIX računalnikih - $47 \%$ deleža.

ORACLE je relacijska baza podatkov (Relational Database Management System - RDBMS), ki je kompletirana $s$ setom integriranih softverskih orodij za razvoj aplikacij in analizo podatkov.

ORACLE - pravi relacijski sistem prinaša mnogo prednosti, kot so:

- lahek dostop do podatkov:

- fleksibilnost $v$ modeliranju podatkov;

- reducirano fizično pomnenje podatkov in redundanca;

- neodvisnost od fizičnega shranjevanja in logični design podatkov;

- visok nivo jezika za upravljanje podatkov (SQL in PL/SGL).

ORACLE RDBMS ima nalogo, da vzdržuje relacijsko bazo podatkov na nivoju administratorja relacijske baze podatkov (Data Base Administrator -DBA). ORACLE RDBMS (ANSI SQL level 2) je popolnoma kompatibilna $z$ IBM SQL/DS in DB2 - zadnja IBM-ova generacija baze podatkov za IBM-ove velike računalnike. Na tržišču je že verzija ORACLE ver. 7.0, katere novost je podatkovna baza s sodelujočimi strežniki $z$ možnostjo prikrivanja razlik med računalniki $v$ omrežju, ki ga sestavlja različna strojna oprema. Omogoča lahko dostop do podatkov, ki so zbrani na več različnih računalnikih, kakor da bi bili na enem samem računalniku.

ORACLE SW vsebuje naslednjo zbirko set integriranih programskih orodij:

- povpraševalni strukturirani jezik (SQL*Plus);

- polnjenje tabele s podatki (SQL*Loader);

- shranjevanje "backup" podatkov (Export/Import);

- generator aplikacij in formatiranje ekranskih mask (SQL*Forms);

- tiskanje poročil (SQL *Reportwriter);

- definiranje zaslonskih menujev (SQL*Menu);

- modeliranje podatkov in procesov (CASE*Method); - slovar podatkov (CASE*Designer);

- predkompajlerji za C(Pro*C), (Pro*Fortran) in Cobol (Pro*Cobol);

- delo z ORACLE v mreži (SQL*Net);

- preglednica za ORACLE (SQL*Calc);

- delo v okenskem okolju (ORACLE*Card). 
GuickSurf ADS verzija je AutoCAD ADS aplikacija za digitalno 2D in 3D modeliranje terena. Njegova moč se pred ostalimi PC DTM kot je na primer DCA DTM ali TIN v PC ARC/Info, odraža predvsem v hitrem procesiranju večjega števila točk $(40.000$ točk/min na PC računalniku i486/33MHz), kar kaže na dobro sprogramiran C program. Ker je QuickSurf razvit v ADS se transfer podatkov med GuckSurfom in AutoCAD-om odvija prek notranje memorije in ne prek ASCII DXF datoteke. S QuickSurf-om lahko obdelujemo TIN (Triangulated Irregular Network) trikotne nepravilne mrežne modele, GRID pravokotne in kvadratne mrežne modele, POINT 3D točkovne modele in CONTOUR 3D linijske (izolinijske) prostorske modele. Obstajo verzije za MS DOS, SUN OS in SCO XENIX.

Novejša verzija GuckSurf 4.5 omogoča todi uporabo lomnih linij "Break Lines), kar je pri modeliranju terena nadvse pomembno.

Geo/SQL je v svojem bistvu sistem za upravljanje s prostorsko bazo podatkov (SPDBMS - Spatial Data Base Management System). Geo/SQL uporablja "moč" SQL relacijskih baz na osnovi ANSI SOL89 standarda in uporabniško univerzalnost AutoCAD-a. Geo/SQL, ki je eden najmodernejših SPDMS, je razvila programska hiša G5 Generation iz USA. Geo/SQL tvori nekakšen "most" med AutoCAD-om (AutoCADI1 in AutoCAD 12) in ANSI SQL RDBMS (ORACLE, R:BASE, GUPTA,...). Tako je Geo/SQL skupaj z AutoCAD-om, AutoCAD aplikacijami tretje generacije in SQL relacijskimi podatkovnimi bazami podatkov zelo močno GIS programsko orodje. Razvojna platforma Geo/SOL-a temelji na ORACLE produktih, zato je dosedaj ORACLE tudi največ uprabljan. Obstajajo verzije za MS DOS na PC in UNIX SUN OS 4.0 na SUN grafičnih delovnih postajah $\mathrm{v}$ enouporabniški (Geo/SQL Profesional) in mrežni verziji (Geo/SQL LANserver). Med MS DOS in OS 4.0 obstaja binarna kompatibilnost, zato Geo/S $3 L$ omogoča povezavo med "low-cost" PC-ji 3386 in i486 ter SUN delovnim postajami. Z obdelavo podatkov RDMBS-a prek SQL-a in $z$ uporabo AutoCAD-a, AutoCAD aplikacij in ostalih, kot so na primer: tekst procesorji, "paint" programi, tabelarični programi (Lotus, Quattro, Excel,..) in drugih "in-house" aplikacij, pa lahko potem kot rezultat te obdelave generiramo najrazličnejše izvedene podatke, na podlagi katerih izdelamo karte, slike, grafe, tabele, tekste, diapozitive, video sekvence in podobno.

Nekatere značilnosti Geo/SQGL-a:

kontinualni-neomejeni objektno orientirani vektorski topološki 2D in/ali 3D prostorski model, ki je omejen le $\mathrm{s}$ hardversko kapaciteto;

- učinkovito delo $\mathrm{z}$ velikimi PC prostorskimi bazami. Na PC računalniku je možno uspešno obvladovati tudi velike prostorske baze (testirano 500MB - grafični in atributivni del) in $s$ tem, da $v$ takšni bazi ni podvajanja, kajti vsaka točka obstoja samo enkrat;

- interaktivno SQL povpraševanje, popravljanje, vnašanje in podobno, hkrati iz prostorske grafične in atributivne podatkovne baze;

- strukturiran neproceduralni jezik. Vsi dostopi do prostorskih podatkov 
so izvedeni $z$ SQL-u podobnimi ukazi in vključuje makro jezik $z$ okoli $150 \mathrm{SQL}$ funkcijami;

- izmenjava podatkov $z$ drugimi GIS programi $v$ formatih kot so: DXF, DXB, IGES ali pa prek GXF (Geographics Exchange Format), ki je odprt ASCII format;

- enostavna povezava $z$ ostalimi AutoCAD programi, kot tudi drugimi programi (klic ostalih DOS programov iz AutoCAD GUI lupine);

- izvorne in uporabniško prilagodljive GIS AutoLISP rutine (preko 200 AutoLisp dokumentiranih programov); avtomatski menu generator AutoCAD-a na SQL ukaze iz RDBMS;

- Geo/SQL je enouporabniško in/ali večuporabniško programsko orodje, katero omogoča kompletno uporabniško definirano grafično in atributivno podatkovno strukturo;

- enostavna prilagoditev AutoCAD menijev.

\section{UPORABLJENA MEHANSKA IN PROGRAMSKA OPREMA}

Matična plošča:

* i486/33Mhz

* 32 MB RAM

Eksterni pomnilnik:

* $550 \mathrm{MB} \mathrm{HD}$

* 60 MB Streamer

Video:

* Grafična kartica:

TIGA in VGA

* monitor $19^{\prime \prime}$ :

TIGA /1280x1024/256 monitor 14 ":

VGA / $800 \times 600 / 16$
- operacijski sistemi:

MS DOS 5.0, MS WINDOWS 3.1

aplikativna orodja:

* AutoCAD ver.11 in ver. 12

* ORACLE ver. 6.0

* Geo/SQL ver.3.1a

* GuicSurf ADS ver. 4.5

* IDRISI ver.4.0

* ROOTS

* CHOPIN

* ScanCAD

* EDSCAN

* CADMate

Skenerji:

* Mono A0, 400 dpi

* Barvni A4, 600 dpi

Risalnik:

* Peresni AO

Tiskalniki:

* InkJet A2, 360 dpi

* InkJet bar. A3, 300 dpi

* Laserski A4, 300 dpi

Digitalnik:

* Format A 1, 1000 lpi

- programski jeziki:

MS Fortran77, LAHEY Fortran77, MS C, AutoLISP, MS Visual

BASIC, MS QuickBasic

+ programski pripomočki za konverzije $\mathrm{v}$ različne formate, komprimiranje datotek, editiranje rastra ...

+ pomožni "domači" pogrami: DMR2XYZ, GeoRav, CnctNode, SepaEnti, CtrlNode, ClrVtx,... 
Slika 10: Risanje lokacij mernih mest piezometrov in vodnjakov (podatki $H M Z$ ).

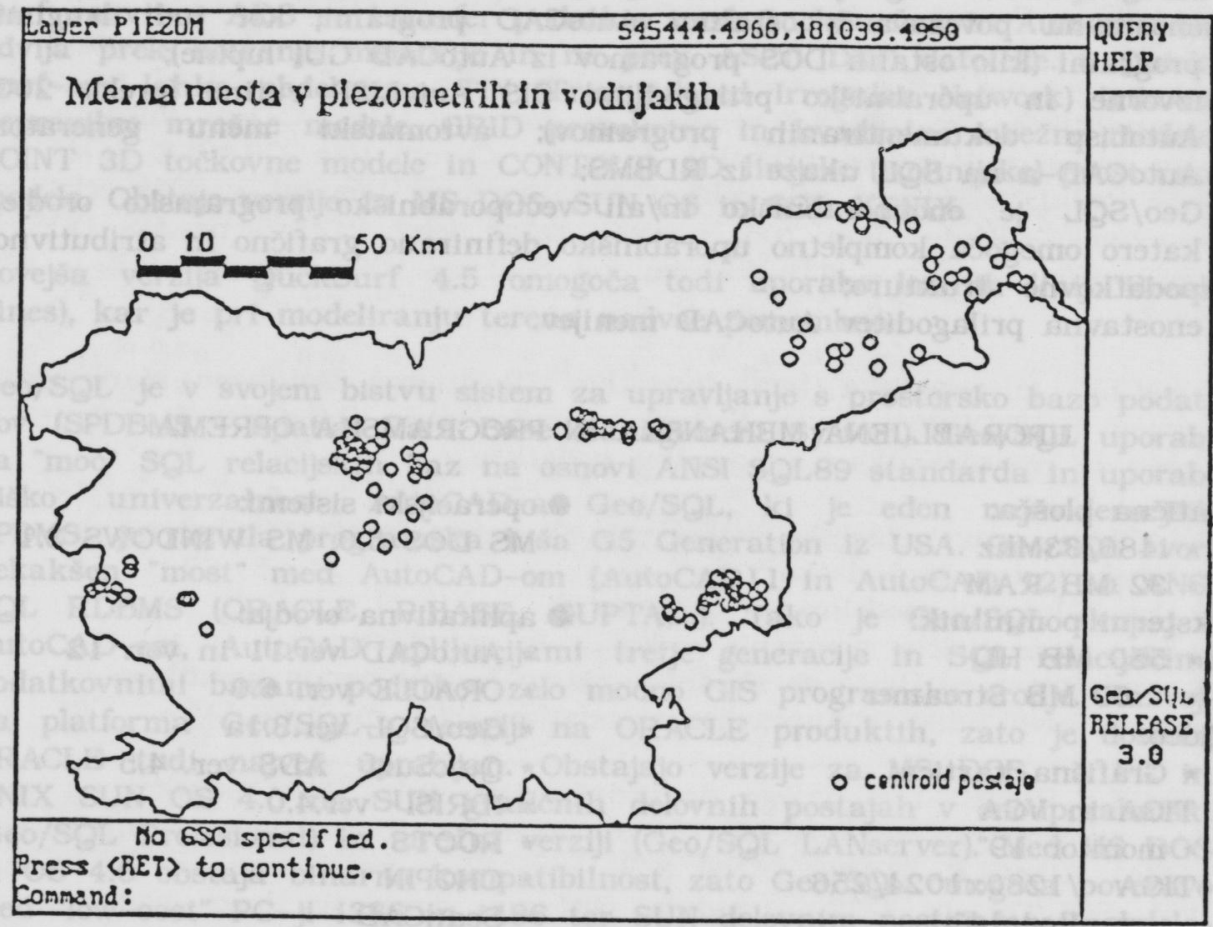

\section{PRIMERI ANALIZIRANJA, TESTIRANJA IN UPORABE Geo/SgL-a}

V geografski informacijski sistem so bili $\mathrm{z}$ Geo/SQL-om za potrebe dosedanjega testiranja GIS in analize obstoječih podatkov vnešeni naslednji podatki:

- kataster onesnaževalcev iz popisa 1986 - slika 2;

- kataster onesnaževalcev iz popisa 1990 - slika 3;

- evidenca kraških jam $z$ vodo - slika 4;

- kataster vodnih izvirov - slika 5;

- evidenca hidroloških postaj - slika 6;

- evidenca meteoroloških postaj - slika 7;

- evidenca postaj meritev podtalnic (piezometri in vodnjaki) - slika 8;

- digitalni model reliefa Slovenije (DMR 100 m x 100 m) - slika 9;

- hidrografska mreža Slovenije (1:250.000) 


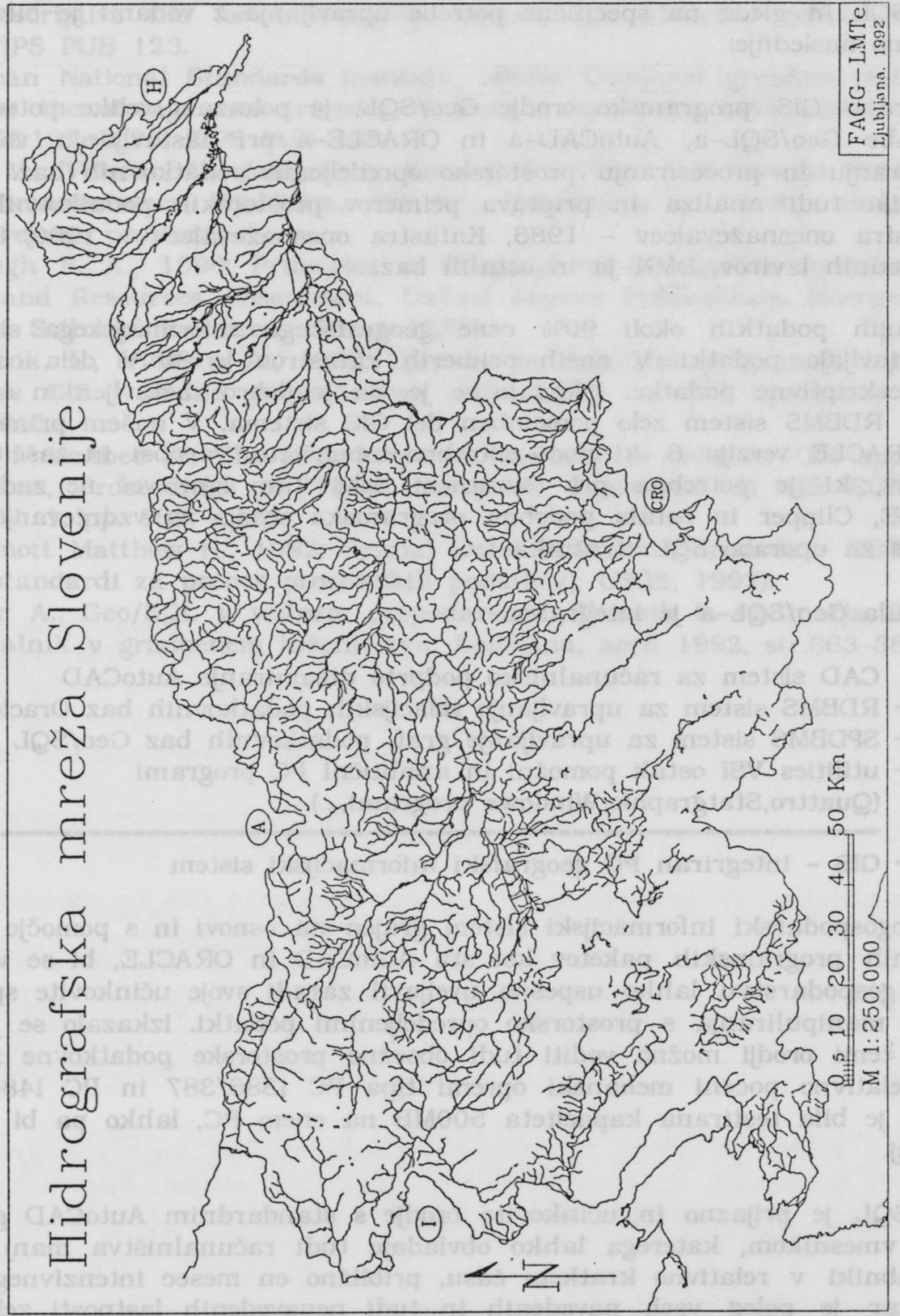




\section{ZAKLJUČKI}

V smislu analize zmožnosti in uporabnosti GIS programskega orodja Geo/SQL in glede na specifične potrebe upravljanja $z$ vodami je bilo ugotovljeno naslednje:

Testirano GIS programsko orodje Geo/SQL, je pokazalo velike potencijale uporabe Geo/SQL-a, AutoCAD-a in ORACLE-a pri nastavljanju, vodenju, ažuriranju in procesiranju prostorsko opredeljenih podatkovnih baz. To je potrdila tudi analiza in priprava primerov prostorskih podatkovnih baz Katastra onesnaževalcev - 1986, Katastra onesnaževalcev - 1990, Katastra vodnih izvirov, DMR-ja in ostalih baz.

Po tujih podatkih okoli $90 \%$ cene geografskega informacjskega sistema predstavljajo podatki. V naših primerih katastrov je $80 \%$ dela odpadlo na deskriptivne podatke. Izkazalo se je, da je dobro zastavljen in organiziran RDBMS sistem zelo pomemben del GIS sistema. V našem primeru je to ORACLE verzija $6, \mathrm{ki}$ nudi potrebno integriteto, varnost in zaščito podatkov, ki je potrebna pri tovrstnem delu. Tam kjer več ne zadoščajo dBASE, Clipper in ostala podobna programska orodja za vzdrževanje baz, je čas za uporabo SQL strežnika-ov.

Formula Geo/SQL-a je integralna:

CAD sistem za računalniško podprto dizajniranje AutoCAD

+ RDBMS sistem za upravljanje relacijskih podatkovnih baz Oracle

+ SPDBMS sistem za upravljanje graf. podatkovnih baz Geo/SQL

+ utilities VSI ostali pomožni in analitični PC programi (Quattro,Statgraphic,Windows programi,...)

= GIS - integriran PC geografski informacijski sistem

Vodnogospodarski informacijski sistem grajen na osnovi in s pomočjo standardnih programskih paketov kot sta AutoCAD in ORACLE, bi se v vodnem gospodarstvu lahko uspešno uveljavil zaradi svoje učinkovite sposobnosti manipuliranja s prostorsko opredeljenimi podatki. Izkazalo se je, da je s temi orodji možno voditi tudi obsežne prostorske podatkovne zapise na relativno poceni mehanski opremi tipa PC i386/387 in PC 1486. Do sedaj je bila testirana kapaciteta 500MB na enem PC, lahko pa bi šlo še naprej.

Geo/SQL je prijazno in učinkovito orodje s standardnim AutoCAD grafičnim vmesnikom, katerega lahko obvladajo tudi računalništva manj vešči uporabniki v relativno kratkem času, približno en mesec intenzivnega dela, kar je poleg vseh navedenih in tudi nenavedenih lastnosti zelo pomembno. 


\section{LITERATURA IN VIRI}

American National Standards Institute, 1986a: Specification for a data descriptive file for information interchange: ANSI/ISO 8211- 1985, FIPS PUB 123.

American National Standards Institute, 1986b: Computer graphics metafile for the storage and transfer of picture description information: ANSI X3.122-1986, FIPS PUB 128.

Brilly M., Vidmar A., Jamnik I., Kovačič S., 1991: Vektorizacija katastra onesnaževalcev, Ljubljana, 25 str., Ministrstvo za varstvo okolja in urejanje prostora.

Burrough P. A., 1990: Principles of Geographical Information Systems for Land Resources Assessment, Oxford Science Publications, Monographs on Soil and Resources Survey,12/90.

Globevnik, L., Vidmar, A., 1992: Uporaba in vključitev programskih paketov GIS v vodno gospodarstvo, arhiv LMTe : d-403, Ljubljana, april 1992.

James 1. McAbee III, The importance of 'opennes' to data for GIS applications, Proceedings of Third European Conference on GIS: EGIS'92, Vol. 1, pp. $163-172$.

McDermott Matthew H., 1992: Spatial Data Transfer Standards - SDTS) (standardi za prenos prostorskih podatkov), USGS, 1992).

Vidmar A., Geo/SQL v vodnem gospodarstvu, Zbornik 6. seminarja Računalnik v gradbenem inženirstvu, Ljubljana, april 1992, str.363-368. 